\title{
ACCIDENTS AMONG MEDIEVAL CHILDREN AS SEEN FROM THE MIRACLES OF SIX ENGLISH SAINTS AND MARTYRS
}

\author{
by \\ ELEANORA C. GORDON *
}

Accounts of recoveries from accidental injuries in medieval children recorded among the posthumous miracles of saints are a particularly valuable source of information about childhood during an age for which such material is scarce. Whereas reports of miraculous healing of chronic illnesses or handicaps often emphasize the prayers offered and the sudden joyous return to health at the shrine in front of astonished worshippers, those describing recoveries from accidents, especially numerous among children, also set down the events leading to the catastrophe. These circumstances, often described in detail, provide excellent evidence about children's behaviour. In addition, the responses of parents, bystanders, and the community to the crises tell us a great deal about family relationships and the status of children in medieval society. These accounts, therefore, reveal the world of medieval childrentheir upbringing, their play and playmates, their work, and their families.

In an age when access to any kind of physician was non-existent for many people, recourse to celestial aid, a natural reaction of pious folk, was the primary form of therapy. People invoked the aid of saints as intercessors for acute and chronic illnesses, disabilities, emotional disorders, and accidental injuries. Those with chronic illnesses or disabilities usually went to the shrine with an offering and often spent one or more nights in prayer. On the other hand, victims of accidents and sudden illnesses, or their families and neighbours, prayed for the saint's aid on the spot or at home, often vowing a pilgrimage and a gift in return for recovery. After a return to health had confirmed the saint's awesome power, the grateful beneficiaries, often accompanied by witnesses, related their experience to a custodian presiding at the saint's shrine or tomb. In accounts of long-standing illnesses or handicaps the custodians who recorded the pilgrims' recitals often pointed out the superiority of the saint's powers over those of earthly practitioners. In some cases religious appeals for help came only after standard medical treatment had failed. In the vast majority, however, recourse to the saints was the only therapy described. Although some descriptions of acute and chronic illnesses contain medical information, many of the records of miraculous recoveries from

\footnotetext{
* Eleanora C. Gordon, MD, Associate of the Francis C. Wood Institute for Research in the History of Medicine of the College of Physicians of Philadelphia. Mailing address: 263 Kent Road, Wynnewood, PA 19096 USA.
}

I am most grateful to Dr Thomas E. Cone, Jr., Professor Nancy Tomes, and Professor Kevin Connolly for their constructive criticism of this manuscript in its early stages. 


\section{Eleanora C. Gordon}

injuries caused by accident or misadventure in children contain especially detailed clinical material. They sometimes read like case histories. The accounts tell of resurrection from apparent death, happy resolution of life-threatening emergencies, recovery from mortal illnesses brought on by a freak accident, and miraculous escapes from calamities with only minor injuries.

There are, to be sure, limitations to the historical validity of an analysis of miraculous recoveries. The subjects are self-selected, and the chroniclers, known and unknown, undoubtedly did not record every recital. We do not know how many petitioners failed to receive help. Parents who appear in accounts of miraculous recoveries among children, who prayed for help, made a vow, and undertook a pilgrimage, obviously cared deeply about their offspring. Indifferent or abusive parents, and there must have been many, do not appear. The material is anecdotal, and the details vary in specificity. The ending is always happy. The telling and retelling of such emotionally-charged tales could well have led to exaggerations. Nevertheless, even with these limitations, accounts of children's miraculous recoveries from accidental injuries provide valuable material about medieval children and about the response of those about them to life-threatening catastrophe. ${ }^{1}$

A systematic analysis of accounts of posthumous miracles depends on the availability of a large number of records carefully compiled rather than random anecdotes about compassionate saints. England from the twelfth through to the sixteenth century had many shrines whose custodians kept careful records which are accessible today. These accounts are among the most detailed in hagiographical literature. Among these tombs and shrines were those dedicated to St Thomas Becket, St Wulfstan, Simon de Montfort, St Thomas Cantilupe, St Edmund the Martyr, and Henry VI, King of England. One hundred and thirty-four children and adolescents injured in 135 accidents and freak occurrences appear in the records of these six saints and martyrs. Although the accounts cover a period of over 300 years, the injuries and the conditions which led to them are remarkably consistent. In this article I will review the accounts of accidents in the young people described in these records. I will analyse the injuries they suffered and the circumstances which precipitated them. A study of the data will demonstrate that despite Ariès's well-known assertion that: "In medieval society the idea of childhood did not exist ... The idea of childhood corresponds to an awareness of the particular nature of childhood ... In medieval society this awareness was lacking", medieval folk did indeed have a notion of childhood. ${ }^{2}$ They were very much aware of typical childish behaviour and had appropriate expectations. Parents loved their offspring dearly and often exhibited grief, guilt, or remorse over the accident. The behaviour and activities of the children and adolescents described were age-appropriate and typical of childhood and adolescence as we understand them today.

\footnotetext{
${ }^{1}$ For an overview of material concerning children in posthumous miracles of saints, see Eleanora $\mathrm{C}$. Gordon, 'Child health in the Middle Ages as seen in the miracles of five English saints, A.D. 1150-1220', Bull. Hist. Med., 1986, 60: 502-22. See Ronald C. Finucane, 'The use and abuse of medieval miracles', History, 1975, 60: 1-10 for a discussion of the caution necessary in the interpretation of miracle stories as historical source material.

${ }^{2}$ Philippe Ariès, Centuries of childhood, trans. Robert Baldick, New York, Random House, 1962, p. 128.
} 
THE SOURCES

Although the shrines of all these saints drew large numbers of pilgrims, there were distinct differences in the mix of petitioners and in the quality and style of the records. The great shrine of St Thomas Becket at Christ Church, Canterbury, began to attract pilgrims of all classes from England, Wales, and Europe within a short time after his murder on 29 December 1170. Benedict of Peterborough and William of Canterbury edited the narratives of the beneficiaries in loving detail between 1170 and $1184 .^{3}$ Because Becket, beloved by the common people, was a martyr, and because his blood, diluted with water from the cathedral cistern, was a uniquely portable relic, his cult grew rapidly. An invocation for aid, administration of "Becket water", and a vow of a pilgrimage were often enough to bring about a recovery perceived as miraculous.

Anonymous chroniclers assembled the records of the miracles attributed to Wulfstan, the great eleventh-century statesman and Bishop of Worcester, after his canonization in 1203. The detailed narrative covers the period between 1203 and 1220.4 His shrine attracted all classes of pilgrims from England, Wales, and Ireland.

The cult of Thomas Cantilupe, Bishop of Hereford, scholar, lawyer, and statesman, grew rapidly after his death in 1282. Miracles attributed to him appear in the form of testimony of beneficiaries and witnesses before the commission of inquiry set up by Pope Clement V in 1306 to evaluate Cantilupe's qualifications for sainthood. ${ }^{5}$ Some reports are, therefore, very detailed. ${ }^{6}$ As the proceedings dragged on, however, and the number of miracles grew ever more numerous, detailed questioning became impossible, and many miracles appear in the record as brief notations.

The cult of St Edmund, the royal Saxon martyr killed by Norsemen in 870, was well established by the tenth century. The most detailed summary of miracles attributed to him, however, that edited by John of Tynemouth, only describes miracles occurring from 1350 onwards. ${ }^{7}$

Two uncanonized "saints", Simon de Montfort, leader of the Barons' Revolt, and Henry VI, King of England, the gentle victim of the Wars of the Roses, became holy martyrs in the minds of the common people. The monks of Evesham Abbey who buried Simon de Montfort's mutilated remains after the battle of Evesham in 1265

\footnotetext{
${ }^{3}$ Benedict of Peterborough, Miracula Sancti Thomae Cantuariensis, in James Craigie Robertson (ed.), Materials for the history of Thomas Becket, London, Longman, 1876, Rolls Series, no. 67, vol. 2, pp. 21-281 (hereinafter referred to as Ben. Pet.); William of Canterbury, Miraculorum gloriosi martyris Thomae, Cantuariensis archepiscopi, in ibid., 1875, Rolls Series, no. 67, vol. 1, pp. 173-546 (hereinafter referred to as Wm. Cant.).

${ }^{4}$ The miracles and translations of St Wulfstani, in Reginald R. Darlington (ed.), The 'Vita Wulfstani' of William of Malmesbury, London, Royal Historical Society, 1928, Camden Series, no. 40, pp. 115-88 (hereinafter referred to as Wulf. chron.).

${ }^{5}$ See Patrick H. Daly, 'The process of canonization in the thirteenth and early fourteenth centuries', in $S t$ Thomas of Cantilupe Bishop of Hereford: essays in his honour, Hereford, Friends of Hereford Cathedral, 1982, pp. 125-35, and Ronald C. Finucane, Miracles and pilgrims: popular beliefs in medieval England, Totowa, New Jersey, Rowman \& Littlefield, 1977, pp. 173-88 for details of St Thomas Cantilupe's canonization.

${ }^{6}$ Miracula S. Thomae de Cantilupe Episcopi, in J. Bollandus et al. (eds.), Acta Sanctorum Bollandiana, Antwerp, Société des Bollandistes, 1765, 1 October, pp. 610-705 (hereinafter referred to as Cantilupe proc.).

${ }^{7}$ John of Tynemouth (ed.), De Sancto Edmundo rege et martire, in Carl Horstman (ed.), Nova legenda Anglie, Oxford, Clarendon Press, 1901, vol. 2, pp. 573-688 (hereinafter referred to as Edmund chron.).
} 


\section{Eleanora C. Gordon}

probably did not wish to encourage a cult which would honour a rebel, but they dutifully made short notations of the accounts of his beneficiaries who came to the abbey to report his aid. ${ }^{8}$ When King Henry VII began canonization proceedings for Henry VI in 1494, the Dean of Windsor asked a monk to compile and edit the notes taken in the vernacular from beneficiaries who visited the royal tomb at Windsor from 1481 to $1500 .^{9}$ The accession of Henry VIII and the subsequent religious upheaval, however, eliminated any prospect of sainthood for his great-uncle. The unknown chronicler produced a literary and polished account with many editorial flourishes and discourses on theology. He also displays an enlightened knowledge of children and their behaviour.

\section{THE SUBJECTS}

The records of miracles attributed to these six saints and martyrs during the years 1170 to 1500 contain accounts of 358 recoveries in 354 children. (Four children were beneficiaries of two miracles. $)^{10}$ One hundred and thirty-five reports, or 38 per cent, describe accidental injuries in 134 subjects (one boy nearly drowned twice). The remainder deal with acute and chronic illnesses, disabilities, and emotional disorders. By contrast only 85 of 1152 adult petitioners ( 7 per cent) sought help for accidental injuries. Adults much more commonly sought cures for chronic diseases or disabilities. Most accidental injuries in adults were work-related or sustained in various forms of combat. Table 1 summarizes the total number of miracles and those concerning accidental injury in adults and children in the accounts of each of the six saints.

Table 1: Accidents in posthumous miracles of six English saints and martyrs

\begin{tabular}{lcclcc}
\hline $\begin{array}{l}\text { Saint or } \\
\text { martyr }\end{array}$ & $\begin{array}{l}\text { Total number } \\
\text { of miracles }\end{array}$ & $\begin{array}{l}\text { Miracles } \\
\text { in adults }\end{array}$ & $\begin{array}{l}\text { Miracles in } \\
\text { children }\end{array}$ & $\begin{array}{l}\text { Accidents in } \\
\text { adults }\end{array}$ & $\begin{array}{l}\text { Accidents in } \\
\text { children }\end{array}$ \\
\hline $\begin{array}{l}\text { Thomas Becket } \\
\text { Wulfstan }\end{array}$ & 556 & 431 & 125 & 23 & 28 \\
$\begin{array}{l}\text { Simon de } \\
\quad \text { Montfort }\end{array}$ & 91 & 64 & 27 & 2 & 2 \\
$\begin{array}{l}\text { Thomas } \\
\quad \text { Cantilupe }\end{array}$ & 191 & 165 & 26 & 7 & 8 \\
$\begin{array}{l}\text { Edmund } \\
\text { Henry VI }\end{array}$ & 650 & 345 & 105 & 28 & 54 \\
\hline Total & 61 & 42 & 19 & 4 & 10 \\
\hline & 151 & 105 & 56 & 21 & 33 \\
\hline
\end{tabular}

\footnotetext{
${ }^{8}$ The miracles of Simon de Montfort, in James Orchard Halliwell (ed.), The chronicle of William de Rishanger of the Barons' Wars, London, J. B. Nichols, 1840, pp. 67-109 (hereinafter referred to as Simon de Mont. chron.).

${ }^{9}$ Paul Grosjean (ed.), Henrici VI Angliae Regis Miracula Postuma, Brussels, Société des Bollandistes, 1935 , pp. 12-307 (hereinafter referred to as Henry VI chron.). For a discussion of the manuscript see Ronald Knox and Shane Leslie (eds.), The miracles of King Henry VI, Cambridge University Press, 1923, pp. 16-29.

${ }^{10}$ Careful reading of the context determined the classification if the age was not given. See Gordon, op. cit., note 1 above, p. 506, for a description of the criteria used to determine the age of a subject.
} 


\section{Accidents among medieval children}

In the group of 134 children and adolescents under study, 81 were boys, 46 were girls, and there are seven whose sex is unknown. The greater number of boys in this series is not surprising. Hanawalt, in her analysis of fatal accidents as seen in coroners' rolls from the late thirteenth to the early fifteenth century, also found a predominance of boys. ${ }^{11}$ Although many hazards are different, more boys than girls are injured in our own day. Rivara et al. have attributed the higher incidence of accidental injury in boys to increased exposure to risk and to sex differences in behaviour. ${ }^{12}$ Both of these factors were likely to have been present in medieval times. It is important to note that in the narratives used for this study, parents of injured girls demonstrated the same degree of concern, grief, and despair noted in the accounts of accidents to boys.

Only eleven accounts fail to mention parents or close relatives. Four of these concern adolescents who were away from home out on their own, and two involve children working as household servants. In these cases bystanders or employers acting in loco parentis offered prayers for their recovery. The brief notations that describe the remaining five children make no specific allusions to parents, but there is no implication that they did not exist. The chroniclers frequently also refer to siblings, nurses, and domestic servants. For the most part the narratives present a picture of children living at home surrounded by family, household help, and friends in a closely-knit community.

Although the records concern all classes, by far the largest number of children came from the middle and lower classes. The chroniclers did not always mention the child's social standing, although they were likely to call attention to miraculous recoveries in children of the aristocracy and gentry and in the poor, since these events brought special credit to the saint.

The ages of the beneficiaries ranged from three weeks through adolescence up to the age of twenty. There were 11 adolescents and 123 children under thirteen in the group. Eighty-one of the accounts mention a specific age. In the others the term "child" (puer) appears. The context suggests that these are young children. Fortyseven (58 per cent) of the children whose ages are known had an accidental injury before their fourth birthday. Hanawalt's study of accidental death in coroners' records show a similar distribution. ${ }^{13}$ Young children, whose judgement has not developed as rapidly as their mobility and independence, have always been at risk from accidental injury.

\section{THE SITES}

The majority of accidents occurred in rural communities, villages, and small towns. Four took place in London. Although most of the children came from England, the Becket miracles do contain recitals given by pilgrims from English possessions in France and from Flanders.

\footnotetext{
${ }^{11}$ Barbara A. Hanawalt, 'Childrearing among the lower classes of late medieval England', $J$. interdisciplinary Hist., 1977, 8, pp. 13, 16.

${ }^{12}$ Frederick P. Rivara, Abraham B. Bergman, James P. Lo Gerfo, and Noel S. Weiss, 'Epidemiology of childhood injuries II: sex differences in injury rates', Am. J. Diseases of Children, 1982, 136, p. 503.

${ }^{13}$ Barbara A. Hanawalt, The ties that bound: peasant families in medieval England, New York, Oxford University Press, 1986, p. 182.
} 


\section{Eleanora C. Gordon}

Most of the accidents took place at home or nearby. Sixty came to grief in their immediate neighbourhood - on the roads, in the ponds, streams, and rivers, and in the pastures. Thirty-eight, many of them between the ages of one and two, received injuries within the walls of their homes, and twenty-five were hurt just outside their houses or in the yard or outbuildings. Two accounts do not mention the site of the accident. Many of the accidents took place at play or during ordinary household activities. Only ten youngsters (three children and seven adolescents) were at work when the mishap occurred. Seven others had accidents when their parents took them along as they did their chores.

\section{THE INJURIES}

The conditions reported are those which would be expected in a group of lively children: near-drownings, head injuries, choking, suffocation, strangulation, fractures, sprains, dislocations, abrasions, contusions, burns, and injuries from a few freak occurrences. Table 2 is a summary of the types of injuries in relation to the age of the victims.

Table 2: Age in relation to accidental injuries

\begin{tabular}{|c|c|c|c|c|c|c|c|c|c|}
\hline \multirow[b]{2}{*}{ Age (years): } & \multicolumn{6}{|l|}{ Under } & \multicolumn{3}{|c|}{ No age } \\
\hline & 1 & 1 & 2 & 3 & $4-6$ & $7-12$ & Over 12 & given & Total \\
\hline Near drowning & 3 & 9 & 5 & 1 & 7 & 7 & 3 & 41 & 76 \\
\hline Concussion & 2 & 0 & 3 & 1 & 1 & 1 & 3 & 6 & 17 \\
\hline Lacerations & 0 & 0 & 3 & 0 & 1 & 2 & 1 & 2 & 9 \\
\hline Choking & 2 & 3 & 0 & 1 & 0 & 0 & 2 & 0 & 8 \\
\hline Suffocation & 5 & 0 & 0 & 0 & 0 & 0 & 1 & 0 & 6 \\
\hline Strangulation & 1 & 0 & 0 & 0 & 1 & 0 & 0 & 0 & 2 \\
\hline $\begin{array}{l}\text { Fractures, sprains, } \\
\text { dislocations } \\
\text { Abrasions }\end{array}$ & 0 & 0 & 0 & 0 & 1 & 0 & 0 & 3 & 4 \\
\hline $\begin{array}{l}\text { Abrasions, } \\
\text { contusions }\end{array}$ & 0 & 1 & 0 & 0 & 0 & 2 & 0 & 0 & 3 \\
\hline Burns & 0 & 1 & 0 & 0 & 1 & 1 & 0 & 0 & 3 \\
\hline Other & 2 & 1 & 1 & 0 & 0 & 0 & 1 & 2 & 7 \\
\hline Total & 15 & 15 & 12 & 3 & 12 & 13 & 11 & 54 & 135 \\
\hline
\end{tabular}

All of these children and adolescents recovered after a fervent invocation to a saint by parents and bystanders and usually the promise of gifts and pilgrimage. The prayers were an instant reaction to a potential catastrophe. There was no time to fetch a practitioner even if one were available. In only three instances, as will be described below, did a physician or a skilled layman examine or treat the child. In a few cases onlookers tried some rudimentary first aid such as bandaging a sprain or suspending a child who had apparently drowned. In these records recovery was usually rapid, eodem die pristinae restitutus erat sanitati, but occasionally recuperation took place over a period of several weeks.

Two peculiarly English rituals often accompanied the invocation and served as emergency, medicine-enhancing prayer. In one, the petitioner bent a penny over the 
injured person and invoked the saint's aid, promising to take that particular penny to the shrine and offer it as a gift. The ritual was extremely common and was used not only for children and adults but also for animals and in life-threatening situations such as shipwreck. ${ }^{14}$ The other consisted of "measuring the person to a saint" with a string. The string, whose length was usually the sum of the person's height and the length of his outstretched arms, became a wick for a votive candle, or served as a measure of how many candles would be bought at the shrine. This ritual, noted in Europe since the sixth century, became especially common in England during the twelfth and thirteenth centuries. As in the case of the bent penny, petitioners used it for children, adults, animals, and emergencies. The commission of inquiry investigating Thomas Cantilupe's qualifications for sainthood describes the ritual as being something novel and English. ${ }^{15}$ The custom, therefore, must have been an uncommon religious ritual in Europe at the beginning of the fourteenth century, although it did persist in folklore. ${ }^{16}$

\section{Near-drownings}

Water was by far the most common hazard for medieval children. It is not surprising, therefore, that the miracle narratives contain many accounts of neardrowning. The return to life of a pale, cold, comatose child with no apparent breath or pulse was to medieval people a true miracle indicative of the power of the saint invoked. All too often drownings were fatal. Seventy-six accidents, over half the total in this group of children, were near-drownings. Twenty children tumbled into pits, ponds, or pools. Four fell into ditches. Eighteen young people, mostly older children and adolescents, nearly drowned in rivers and streams. Wells attracted seventeen toddlers and young children. Thirteen fell into such assorted bodies of water as harbours, rain barrels, bathtubs, wine vats, and ale casks. Mill wheels were a common hazard. Four children fell into mill races and were swept under the wheel. One lucky baby, who had crawled to the edge and tumbled over, survived when the paddle scooped him up and his family plucked him out from between the blades at the top of the cycle. ${ }^{17}$

Although modern medicine recognizes that survival is possible after long submersion, the details of recoveries of children after "hours" under water need not be taken literally. Recollections of excited witnesses may have been imprecise. Estimation of time was inexact. Elapsed time was estimated by canonical hours or by comparison with a known interval, such as walking a certain distance. ${ }^{18}$ Although the details may have reflected what the beneficiaries wanted to believe rather than what actually happened, there is no doubt that the accounts of near-drownings do tell us that the children came close to death.

\footnotetext{
${ }^{14}$ For a discussion of the ritual of bending a coin, see Finucane, op. cit., note 5 above, p. 94.

15 "Jam dixi supra, hunc morem in Anglia fuisse, ut, quas alicui Sanctos commendatos vellent, eos mensurarent, atque hoc ritu, quasi Sancto illi voverunt, ac deinde ipsam mensuram, aliquando cereo insertam, ad ejusdem Sancti sepulcrum offerent: quod cum saepius in his miraculis recurrat, suffecerit hic denuo dixisse". Cantilupe proc., p. 613.

${ }^{16}$ See Eleanora C. Gordon, 'Measurement for a votive candle: a rite of healing', Storia $e$ Medicina popolare, 1989, 7: 3-16 for a discussion of the ritual.

${ }^{17}$ Simon de Mont. chron, p. 86.

${ }^{18}$ For example, "... tanto tempore quanto posset miliare unum communi passu ab homine, ut praemittitur, peragrari”. Cantilupe proc., p. 678.
} 


\section{Eleanora C. Gordon}

\section{A miracle attributed to St Thomas Becket is a typical recital:}

Bobby [Rodbertulus], son of Liviva of Rochester, fell into the Medway while playing with friends and sank under the water. The boys who were with him scattered, shouting that Bobby had fallen into the river. A crowd gathered and tried in vain to find the boy. His mother hurried out, shouting an invocation, "Oh, Thomas, glorious martyr of God, return my son to me". These words, her only cry, rang out over and over. It was mid-afternoon when he tumbled in, and dusk was beginning by the time some men pulled him out with an iron hook. The child, who had fallen in at high tide, had been drawn by the current almost to the place where the bay meets the sea. The boy, ghastly pale, was suspended by his feet, and an iron bolt was put into his mouth to open it so that the salt water which distended him could run out. He was silent and senseless, and not a single drop of water flowed. He was spun then in a trough to make him vomit. Nightfall came, with no progress. The boy lay without a single breath of life, and many were saying he was dead. Then his mother, calling on the Martyr, measured the boy with a string and vowed a silver thread of that length in return for his life. At that very instant he vomited all he had taken in and was immediately restored to health. On the next day he played with his friends as usual ... 19

The mother's vow of a silver thread equivalent to the string's length was most unusual. Perhaps she was a wealthy widow.

\section{Concussion}

Accidents resulted in concussion in seventeen children. The duration of unconsciousness ranged from a few minutes to seven days. Families and friends of the injured children, as in the near-drownings, could not distinguish coma from death. Medieval youngsters, like children today, fell out of trees, and off walls and other high places. Farm carts hit some of them, and two were kicked by unruly horses.

At least four of the children sustained skull fractures. A cooking pot which had broken loose from a wooden support crashed on to the head of a two-year-old boy. Recovery followed the administration of Becket water, and the grateful parents exhibited their son at Canterbury along with the fourteen fragments of bone which had sloughed out of his skull during healing. ${ }^{20} \mathrm{~A}$ five-year-old girl happened to be standing directly behind a tardy courier's horse when the rider suddenly applied his spurs. The horse kicked with such force that the blow drove the child's head against a nearby wall. Bystanders administered two doses of theriac, liquor tiriacum, to no avail. She recovered after prayers to King Henry. ${ }^{21}$ A nine-year-old schoolboy happened to wander among some men casting stones, a traditional form of recreation. One stone, "so large that the strongest man could not hurl it twelve feet", hit the boy. His father, a priest, thought he observed a tear in the covering of the brain, and, knowing the poor prognosis, vowed his son to St Thomas Becket. The boy

${ }^{19}$ Ben. Pet., p. 226. This translation from the Latin and all others are my own.

${ }^{20}$ Wm. Cant., p. 203.

${ }^{21}$ Henry VI chron., pp. 178-81. Theriac, a Galenic concoction of vipers' flesh, herbs, and animal and mineral substances, was a traditional antidote for snake bites and poisons. By the fifteenth century it was common therapy for a variety of conditions. See Gilbert Watson, Theriac and mithridatum, London, The Wellcome Historical Medical Library, 1966. 
recovered after a nocturnal vision of the saint. ${ }^{22}$ Emeline was throwing pebbles from a castle wall at children below when she lost her balance and fell. She was unconscious and bleeding profusely from the mouth, nose, and ears when revived by Becket water administered by a passing pilgrim. William of Canterbury, unfailingly solemn in his remarks, took a dim view of Emeline's childish play. "Play leads to sorrow. Sometimes it promises laughter and gaiety, but more often brings forth sadness". ${ }^{23}$

King Henry's chronicler was more tolerant of the consequences of youthful exuberance when he related the miraculous cure of a boy knocked senseless by a thirty-foot fall from a tree. "I do not really know", he wrote, "what childish enthusiasm [led him to climb]. Perhaps it was to take some little birds from the nest". ${ }^{24}$ King Henry's chronicler might have robbed a nest or two in his youth.

Not all falls were from high places. One baby girl managed to overturn her cradle and fall face down on the floor. ${ }^{25} \mathrm{~A}$ seven-year-old tripped over her own threshold. ${ }^{26}$

\section{Lacerations}

There were nine miraculous recoveries from lacerations so severe that bystanders considered exsanguination a likely possibility. Knives caused four wounds. In one case a girl, sent to a school by her parents who had high hopes for her, received a stab wound in the groin from a pocket knife (artavus) during some roughhousing outside the building. Her classmates immediately scattered, and the patron of a nearby church (the patronus ecclesiae) and his vicar found her alone and bleeding profusely as she called on St Thomas Becket for help. They aligned the edges of the wound and stitched it together with "a thread of pure silk". On the following day there was not even a scar. ${ }^{27}$ Although the use of silk sutures had been known in England at least since Anglo-Saxon times, it is indeed surprising that the patron and the vicar not only had the surgical skill to do a neat repair but also had the materials at hand. ${ }^{28}$

Iron pitchforks caused two serious injuries. An adolescent farm worker fell from a pile of straw onto the upturned pitchfork of a helper. One prong struck her in the throat, the other under the jaw, "nearly as far as her left ear". ${ }^{29}$ A father threw his pitchfork into a pile of thatch, hitting his little daughter who was playing underneath. His employer, the lord of the manor, hastened to the site of the accident and pulled the pitchfork out of her scalp. The child was just two, and bystanders feared she would not recover because of her tender years. A medicus, summoned to the scene,

\footnotetext{
22 "Videns pater eius quia cerebrum laesis miringis excuteretur, quod factu potissimum judicavit ...", Wm. Cant., pp. 341-2. Gilbertus Anglicus wrote that, if the coverings of the brain were injured death would occur within 100 days. Henry E. Henderson, Gilbertus Anglicus: medicine of the thirteenth century, Cleveland, Cleveland Medical Library Association, 1918. Priests had not been allowed to marry since the eleventh century, but in the twelfth century many of the lower clergy, especially the parish priests, still resisted celibacy. They were devoted parents.

${ }^{23}$ Wm. Cant., p. 443.

${ }^{24}$ Henry VI chron., pp. 101-3.

25 Cantilupe proc., pp. 686-7.

26 Wm. Cant., pp. 209-10.

27 Ibid., pp. 395-6.

${ }^{28}$ See, for example, The Leech Book, in Oswald Cockayne (ed.), Leechdoms, Wortcunning, and Starcraft of early England, London, Longman, Green, Longman, Roberts \& Green, 1865, Rolls Series, no. 35, vol. 2, p. 57.

${ }^{29}$ Henry VI chron., pp. 246-7.
} 


\section{Eleanora C. Gordon}

thought the brain was injured and gave a gloomy prognosis. The child recovered after the lord and his lady prayed for her at Canterbury. ${ }^{30}$ Domestic animals could and did inflict injury on medieval children. A cantankerous ox goaded once too often by an inexperienced eight-year-old ploughboy charged him and gored him in the throat. ${ }^{31}$

\section{Choking, suffocation, strangulation}

Rescues from asphyxia caused by choking, suffocation, and strangulation appear in sixteen accounts. In medieval times, as now, small children put small objects in their mouths. King Henry's chronicler was well aware of the tendency, "... while he was playing with it he finally put it in his mouth as babies often do". 32 One baby choked on a ring given him by his mother to quiet him as he lay fretting in his cradle. ${ }^{33}$ Others aspirated such varied objects as jewellery, a brass pin, and a silver groat. One infant even choked on a pilgrim's badge of St Thomas Becket. His frantic father's efforts to remove the obstruction with his fingers only made things worse. The baby coughed up the badge after his father prayed desperately to King Henry for help. ${ }^{34}$

Suffocation nearly claimed the lives of five babies who were sleeping in beds with adults. ${ }^{35}$ Nurses rolled on three infants and mothers overlay two. It is noteworthy that all episodes of suffocation from overlaying in this series are found in the Cantilupe miracles. Co-sleeping was certainly a very common practice, and one would expect to find descriptions of recoveries from overlaying in the miracles of the other saints studied here. On the other hand, overlaying might often have had a fatal result. Indeed the Church, aware of the danger, forbade the placing of an infant in bed with adults, and investigations of death from overlaying were common in fifteenthcentury church records. ${ }^{36}$ Although infanticide could theoretically come under the jurisdiction of secular courts, in practice it was a crime left to the Church to punish. ${ }^{37}$ It is not surprising, therefore, that Hanawalt notes only one case of homicide from overlaying in coroners' rolls of the period. ${ }^{38}$

The only other description of suffocation involves an industrial accident which befell an adolescent girl at work in a sand pit. One of the walls caved in on her, burying her with "no less than a hundred wagon loads of sand". She prayed to King Henry while her co-workers dug her out. She emerged grossly swollen and barely breathing but recovered after a group prayer by all present. ${ }^{39}$

King Henry's chronicler tells of two recoveries from strangulation attributed to his saint. Joan, an inquisitive four-year-old left alone to play while her parents were busy,

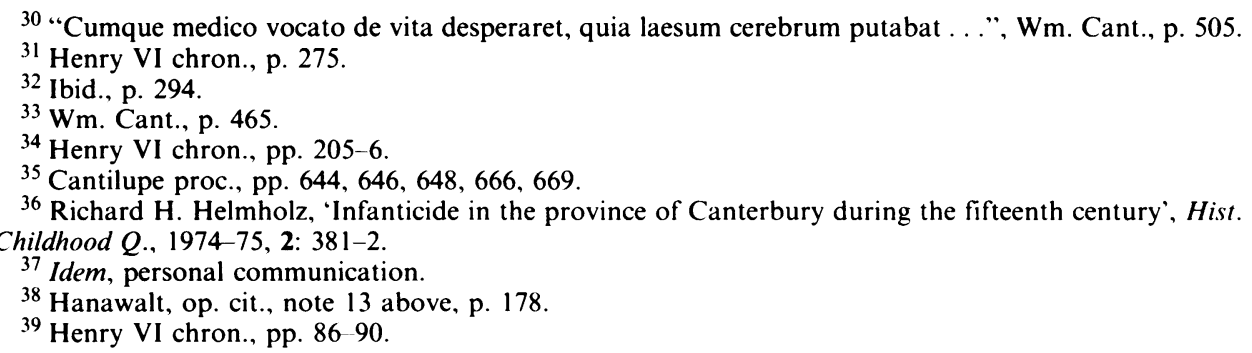


managed to hang herself from a leather thong cut from a woman's purse which held the two halves of a cellar door together. ${ }^{40}$ Six-month-old George, improperly swaddled, nearly strangled himself as he tried to get out of his cradle. King Henry's chronicler notes that he was loosely wrapped in cloth, not bound as he should have been, and restrained by only a single band across his chest. The chronicler also remarks that a string across the cradle held a rattle. ${ }^{41}$

\section{Fractures, sprains, dislocations}

Although many fractures, sprains, and dislocations must have healed spontaneously in medieval times, there were four children in the group whose injuries caused prolonged misery. One litle girl in Flanders stepped into a snare and "broke" her leg while out with her father, a falconer. Her parents, believing she would die if her leg did not heal, wrapped it with a bandage in which they folded a silver coin. They promised St Thomas Becket that coin and one like it every year in return for her recovery. Benedict reported that the "silver plaster" did its work, and the little girl was scampering about eight days after the injury. ${ }^{42}$

A devoted nurse sought help for her wealthy employer's son when a young servant apparently dislocated the child's arm while playfully tossing him about. The servant, terrified, secretly brought the crying child to his nurse. The nurse, though upset to the point of weeping, soothed the boy, bandaged his arm and put him to bed. After he had finally dropped off to sleep she decided that he might be helped by a vow of a pilgrimage to the shrine of St Edmund. When the boy awoke, his arm was completely normal. ${ }^{43}$ One wonders if the parents ever learned of the mishap.

A father's devotion shines through the description of the cure of Alice of Lonesdale's right ankle, fractured in 1292 at the age of five when she stepped into a pothole on the road to London..$^{44}$ The clinical details are graphic. Within a few days after the fall the ankle began to suppurate and swell. One hole discharging pus was so large that her father could see pieces of bone. Her misery increased when she awoke one morning with a left-sided paralysis after sleeping in a doorway in Southwark. Master Gilbert, a sympathetic London surgeon who had noticed her bathing her ankle in the fountain of the church of St Clement Danes, applied a plaster but informed her father that the wound was incurable. Father and daughter abandoned their original itinerary, a pilgrimage to the shrine of St James of Compostella, and wandered, begging, for ten years. She could only drag herself on the ground by using her right arm. Finally her devoted parent bent a coin to St Thomas Cantilupe and trundled his daughter in a wheelbarrow all the way from London to Hereford. After a week of nocturnal visions at St Thomas's shrine, she gradually regained the use of her limbs, the bloody discharge from her ankle dried up, and she could once again bear weight on her right ankle. The ankle healed completely, although a shortened heel

\footnotetext{
40 Ibid., pp. 141-3.

41 .. . . nonquidam fasciatum ut solito." .. . . crepundium tali videlicet arte fabricatum ut agitando facilius moveretur". Ibid., pp. 260-3.

42 Ben. Pet., p. 309.

43 Edmund chron., pp. 684-5.

${ }^{44}$ Cantilupe proc., pp. 7014.
} 


\section{Eleanora C. Gordon}

cord left her with a limp. ${ }^{45}$ Some scars from the healed ulcers and monthly pains in her joints were the only other residual effects of her injury.

\section{Abrasions and contusions}

Abrasions and contusions would not ordinarily constitute miraculous recoveries. However, three children survived life-threatening situations with only scrapes and bruises after appeals to saints. Their parents considered their survival and the minor injuries sustained indicative of the saint's power. An eighteen-month-old infant escaped with only a bruise above his eye when the thirty-foot stone wall of his house collapsed on him as he lay sleeping in his cradle. His frantic mother appealed to St Thomas Becket for aid before she fainted with anxiety. Neighbours and servants searched through the rubble and found the baby happily playing amid the eighteen fragments of his shattered cradle. ${ }^{46} \mathrm{~A}$ twelve-year-old boy standing in a doorway in London had a narrow escape as an enraged bull fleeing from a bull-baiting area trampled on him. His mother's loud invocation of St Thomas Becket's name brought the bull, dogs, and a pursuing crowd to a standstill. The boy received only a few bruises on his chest. ${ }^{47}$ An eight-year-old boy riding on a wagon load of wood tumbled off and fell under a wheel which passed over his chest and throat. Accompanying carters promptly invoked King Henry's aid as they saw him fall. He got up only slightly bruised. ${ }^{48}$

\section{Burns}

It is surprising that only three children in the group received accidental burns. The presence of open hearths and flying sparks in medieval households were a constant hazard. Indeed Hanawalt has cited cradle fires as the leading cause of accidental death among infants and pointed out the frequency with which unsupervised children died in house fires. ${ }^{49}$ It is quite likely that survival from severe burns was the exception. A pot of beans, boiling hard, tipped over on an unlucky seven-year-old, scalding him badly. ${ }^{50} \mathrm{~A}$ freakish injury resulted when a four-year-old boy was pushed into the hearth during an altercation between some servants. ${ }^{51}$ Parental carelessness led to a near-tragedy when a fifteen-month-old baby, left alone at home while his parents went to vespers at a nearby church, fell backwards onto the hearth with his head in the coals. As his parents approached the house after the service, they smelled the odour of burning fat. Accompanied by a crowd of neighbours they hastily entered their home to find their son scarcely breathing, his scalp completely singed and his hand and face horribly swollen. The entire group, overcome with grief, knelt while the father prayed for assistance to King Henry and pledged a pilgrimage to his tomb. Within an hour the boy began to revive, and four months later the burned scalp had sloughed off and healthy new skin had taken its place. ${ }^{52}$

\footnotetext{
45 "Nervus vero pedis dextri retro cavillam, (id est, tibiam ab Italia voce caviglia) prope quam fuerant dicta vulnera, et aliquantulum retractus". Cantilupe proc., p. 702.

${ }^{46}$ Ben. Pet., pp. 252-3; Wm. Cant., pp. 200-2.

${ }^{47}$ Wm. Cant., pp. 292-3.

48 Henry VI chron., pp. 247-50.

${ }^{49}$ Hanawalt, op. cit., note 13 above, p. 175.

${ }^{50}$ Edmund chron., p. 661.

51 Simon de Mont. chron., pp. 84-5.

52 Henry VI chron., pp. 156-9.
} 


\section{Accidents among medieval children}

\section{Miscellaneous injuries}

Some children were the victims of freak occurrences. In several cases foreign bodies caused immediate discomfort and long term chronic infection. Segiva, daughter of Richard of Essex, aspirated a grain of wheat while playing with friends on the threshing room floor. The lingering illness which followed ended dramatically two weeks after the administration of Becket water when the child coughed up the grain. ${ }^{53}$ King Henry's chronicler described a similar accident 300 years later when a toddler put a grain of wheat in her mouth as her mother was threshing. ${ }^{54}$ The grain stuck in her throat and prevented her from swallowing. When caresses failed to stop the little girl's crying, the mother called in her neighbours. The child would not touch the soft food they brought and refused to nurse. After "seven weeks and four days", when the child appeared moribund, her mother invoked King Henry's aid, bent a penny over her daughter, and vowed a pilgrimage to Windsor. As soon as her mother had finished her prayer, the child vomited up the grain of wheat and began to eat and nurse again. One little boy's distress lasted only overnight. He had thrown a handful of pebbles into the air when called in from play by his mother. Acute misery followed when one fell in his ear. He thrashed about and howled so much with pain that his parents had to tie his hands. The pebble, encrusted with blood, fell out as soon as his parents vowed a pilgrimage to Canterbury. ${ }^{55}$

\section{THE CAUSES}

The causes of the accidental injuries described in this series are those which are prevalent today - custodial oversight, normal childish behaviour, and misadventure, or a combination of all three. The compilers of the accounts of the miracles were well aware of these factors and often pointed them out.

\section{Custodial oversight}

Inadequate supervision, often combined with poor judgement or incompetence, was the major cause of accidents described in this study. The oversight was often inadvertent. Mothers, preoccupied with household tasks, could not always keep track of their children. Edith Drake sent her eighteen-month-old son John out to play in the road with other children while she swept her house free of straw, manure, and other accumulated debris. John wandered off and fell into a watering pond. ${ }^{56}$ Another mother, absorbed in washing and bleaching her best clothes in the sun in preparation for the feast of St James, did not pay attention to her two-year-old son who went out of the house and fell into a pond in the neighbourhood. ${ }^{57}$

Sometimes the parents turned their children over to custodians who were unsuitable. A Flemish sailor took his two-year-old daughter along when he went to join others repairing their boats on the beach. He later remorsefully admitted that he had imprudently turned her over to a girl "too young to be a proper guardian". When

53 Ben. Pet., p. 208.

54 Henry VI chron., pp. 21-3.

55 Ben. Pet., pp. 200-1.

56 Cantilupe proc., pp. 614-15.

${ }^{57}$ Henry VI chron., pp. 194-6. 


\section{Eleanora C. Gordon}

a big wave caught the two girls as they played in the water, the older girl managed to hold onto a pier, but the little one went under. A sailor pulled her out. ${ }^{58}$ Older siblings were not always reliable. One mother left her six-month-old baby in a bathtub with his three-year-old brother who was to keep an eye on him while she went to thresh barley. The little one slipped under the water after the older boy climbed out and went off to play. ${ }^{59}$ Sibilla left her daughter, just four months old, in her cradle in the care of another child when she went out to shear a sheep. She returned to find the baby's apparently lifeless body hanging head down, tangled in the bands used to tie her in the cradle. ${ }^{60}$

There were a few occasions when little children were left alone in the house. King Henry's chronicler was outraged at the negligence exhibited by the parents who left their fifteen-month-old son alone in front of a burning hearth while they went off to vespers. "May those who look after little children and who bring up their sons with diligence be warned by this example which shows how much danger and distress carelessness of parents can bring... For they certainly were not unaware of an infant's weakness and of the fact that babies of that age can scarcely get around by leaning on benches and stools unless they crawl or walk". ${ }^{61}$

\section{Normal childish behaviour}

Normal age-appropriate behaviour brought on many accidents. Infants put things in their mouths and choked. Agnes, aged two, put a plum pit up her nostril, "playfully, as little children do". A foul-smelling discharge began to flow from the child's swollen nose in spite of her parents earnest efforts to remove the pit. Agnes's condition grew worse over a period of six months until her desperate mother prayed for King Henry's intercession. Three days later the pit popped out. ${ }^{62}$ Some little children came to grief through inexperience. A father explained to William of Canterbury how his little daughter had neither the judgement to avoid falling into a well nor the skills to keep herself afloat. An appeal to St Thomas Becket had revived her. ${ }^{63}$

Toddlers wandered away happily, puerili levitate vagabundi. Some were persistent and got into trouble far from their own back yards. William, aged two, slipped away from an eleven-year-old servant girl to follow his mother who was walking to a neighbour's house for dinner. He fell into a river through a hole in a foot bridge. ${ }^{64}$ Two-year-old Roger, son of one of the cooks of the household of Conway Castle, wriggled out of his cradle, leaving restraining bonds and his nightclothes behind, while his parents attended an all-night funeral service at a nearby church. He went out into the street, leaving his sleeping sisters, and headed for the castle, "a stone's throw

\footnotetext{
${ }^{58}$ Wm. Cant., p. 202.

59 Ben. Pet., p. 227.

${ }^{60}$ Cantilupe proc., pp. 643-4.

61 "Audiant et auscultent qui parvulos nutriunt, et qui educandorum filiorum curam gerunt presenti moneantur exemplo, quantis periculis et erumpnis infantes exponit parentum incuria ... Non enim ignorare poterant imbecillitatem infantuli, et etatem illam vix sufficere ut vel formis vel scannis innitendo valeret incedere, quin reptando pocius quam gradiendo aream circumire". Henry VI chron., pp. $156,157$.

62 Ibid., pp. $164-5$.

${ }^{63}$ Wm. Cant., p. 522.

${ }^{64}$ Ibid., pp. 615-18.
} 


\section{Accidents among medieval children}

away". Sometime before dawn he tumbled into the dry moat, for the drawbridge over which he usually crossed when visiting his father at work had been raised during the night. At daybreak some of the castle staff happened to see Roger's nude body covered with frost on the bottom of the moat. A citizen of the town, who happened to be passing by, went down and, kneeling beside the boy, took a coin out of his purse, made the sign of the cross with it over the boy's forehead and chest, and vowed a pilgrimage on foot to Hereford if St Thomas Cantilupe would help bring the child back to life. At that moment Roger began to stir. Alerted by the finders at the castle, his distraught parents arrived at the moat just as Roger began to show signs of life. Friends had to restrain his mother from throwing herself into the moat until men could hand him up to her. As soon as she held her son in her arms, she tore open her dress and held him close to her skin to warm him up. After he revived she nursed him, and he was soon happy and laughing. ${ }^{65}$

At least one toddler wandered off in spite of adequate supervision. Eighteenmonth-old Gilbert slipped out of the room where his mother, his nurse, his sister, his brother John, and a servant, and some other women of the household were busy with their work. When John went out of the room a very short time later he found Gilbert head down in a rain barrel full of water with his feet caught on the lip. The family extracted him, and he revived after measurement with a string for a candle and prayers to St Thomas Cantilupe. ${ }^{66}$

The normal exuberance of some older children brought on trouble as they threw themselves into activities, puerili studio. Nine-year-old Joan tripped and fell on a knife she was holding as she and some friends were running around a garden "as girls do". ${ }^{67}$

The behaviour of Hugh Ridel, son of the castellan of one of the King of Scotland's castles, was typically adolescent. He derided a pilgrimage to Canterbury proposed by a friend, saying he was not in the mood for a journey. At a castle banquet a few days later Hugh engaged in some childish horseplay with friends sitting beside him and choked on a piece of meat. Bystanders pounded him on the back with no result. $\mathrm{He}$ recovered after his brother bent a penny to St Thomas Becket, vowed a pilgrimage, and administered Becket water. ${ }^{68}$

\section{Misadventure}

Some children were just unlucky. One boy, for example, nearly drowned when a wayward pig pushed him into a harbour. ${ }^{69}$ Occasionally a chronicler viewed a misadventure as the work of the devil. When a little girl, not yet two, gashed herself with a knife, King Henry's chronicler wrote, "that sly plotter against man's salvation arranged a killing. How and when will he, a murderer from the beginning of time ever be satisfied with blood"? ?0

\footnotetext{
${ }^{65}$ Cantilupe proc., pp. 626-8.

66 Ibid., p. 701.

${ }^{67}$ Henry VI chron., p. 62.

68 Wm. Cant., pp. 327-8.

${ }^{69}$ Edmund chron., p. 680.

${ }^{70}$ Henry VI chron., p. 63.
} 


\section{Eleanora C. Gordon}

FAMILY AMD COMMUNITY REACTIONS

Whatever the cause of the accident, the parents of these children were often beside themselves with grief, and their pleas for celestial aid were tearful and desperate. Neighbours frequently shared the agony. "There arose then among them a continuous despairing wail and loud cries, and these lamentations even reached the heavens, while, of course, both parents with many tears, begged along with the bystanders for God's help, and that of his most worthy knight, King Henry" ${ }^{71}$ When a stray arrow struck a four-year-old boy in the eye while he watched a group of older boys at play, the entire community rushed out to help. The parents of both the wounded child and the boy who fired the shot joined together to pray to King Henry and the Virgin Mary for help. ${ }^{72}$ Neighbours shared the grief of the mother of little Anne Plott over her child, apparently killed when a hit and run driver of a cart full of dung had left her "flat as a pancake" on the public road. ${ }^{73}$ While the mother raged against the carter, a kindly neighbour bent a coin over the body. Anne promptly regained consciousness and cried for her mother.

Many parents expressed remorse along with their grief. One mother begged St Thomas Becket for help for her five-year-old daughter who had apparently drowned: "Return my daughter to me, O Martyr Thomas. If anyone is guilty, I alone, her mother, must bear the blame. I, who did not order supervision of her childish wandering. I should have had a servant accompany my child, but I was blind". ${ }^{4}$

Some children rose to the occasion and acted responsibly during an emergency. Two small boys made a determined and thorough search along a river bank for their older brother, aged six, "although they were little children and inexperienced in judgement". ${ }^{75}$ They found him hanging head down in the river with his coat caught on a branch. The little boys hastened to their mother who fell to the ground "as if a lance had pierced her heart" on hearing the news. A passing youth lifted the boy out. In another instance two boys searched for a playmate and found him head down with his head in the mud at the bottom of a well. They pulled him out and, "there being no human aid nearby", successfully invoked the aid of St Thomas Cantilupe. ${ }^{76}$ One Kentish youth pulled a little girl out of a well and vowed he would eat no meat or fish until he had made a pilgrimage to pray for her recovery at King Henry's shrine at Windsor. $^{77}$

The most detailed miracle in the series, one attributed to St Thomas Cantilupe, epitomizes the information available about medieval children and their world found in accounts of miraculous recoveries from accidental injuries. A summary of the extensive testimony given by no fewer than ten witnesses before the commission of inquiry in 1307, fifteen years after the accident, shows a childish prank, a mother's despair, and the community's support in the face of near-tragedy:

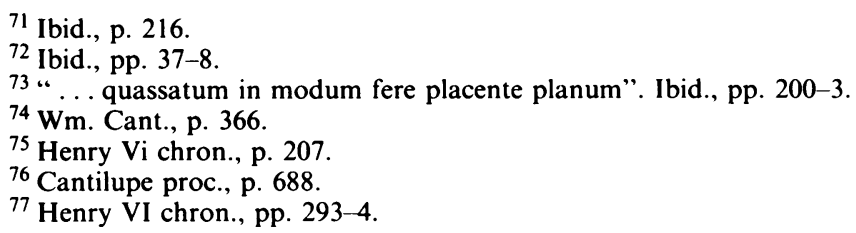




\section{Accidents among medieval children}

One Sunday in late April, 1292, Adam and Cecilia went to a nearby alehouse (taberna cervisiae) to spend the afternoon with friends. They sent their daughter, Joan, aged five, home with her brothers and sisters. Joan broke away from her siblings and followed her parents into the tavern. Seeing that there were other children of her age about, they allowed her to remain. Eventually Joan, along with John, the son of her godmother, and two other children went out into a garden behind the tavern to play. They threw pebbles into a fish pond from the bank six feet above the surface of the water. John pushed Joan in order to frighten her, and she fell into the pond. John and the two other children ran off. Joan clutched at the grassy bank for a while, but her cries for help were unheard and she sank.

A group of young adults came out of the tavern into the garden to dance. Seeing the child's body lying at the bottom of the pond, they assumed it was the daughter of Christina, a beggar woman who they thought had drowned her child in a fit of rage and despondency at her wretched existence. The dancers, wishing to avoid appearing at an inquest, decided not to send for the coroner, and they planned to put the body secretly in a nearby river at nightfall. One among them, a servant, wanted to tell his master, the tavern keeper, but the others would not let him leave.

Meanwhile John went into the tavern to tell Joan's mother what had happened. Just as he was beginning to describe the accident, his father, who had led the dance, thinking he was about to disclose the presence of a corpse, pulled him away and took him home. John, however, returned to the tavern as soon as he could and told Cecilia that Joan had fallen into the fish pond. Cecilia and his mother, who was Joan's godmother, rushed out to the water. Cecilia, eight months pregnant, could only weep, but John's mother, spying the body on the bottom of the pond jumped in, pulled her up, swam to the shore and handed the apparently dead child up to bystanders on the bank. Joan's face was so swollen that her mother did not recognize her at first but soon identified her by her newly-bought shoes with red thongs. By then 40 men and women had gathered and had begun to pray to St Thomas Cantilupe for help for the little girl. Her father measured her to the saint for a candle. The crowd many of them on bare knees, kept a vigil until midnight.

Bystanders, fearing for Cecilia's pregnancy, persuaded her to go to her own home. Clutching her cold and apparently lifeless child, she lay in a bed pulled close to the hearth. At dawn the little girl began to revive in her mother's arms. As soon as her daughter's breathing became regular, Cecilia put her mouth to Joan's ear and asked what had happened. "John pushed me", she replied. ${ }^{78}$

One has to admire little John in spite of his prank. After he thoughtlessly shoved his lifelong playmate over the steep bank and into the water, he knew he had to tell her mother, and his, who was sitting with her. His father's interruption must have bewildered the little boy, but he resolutely escaped from his home and hurried back to tell of Joan's accident.

We must also respect Joan's godmother who had no hesitation about plunging into the six-foot-deep pond. She is one of the very few swimmers described in the accounts of near-drownings. Most children were fished out with poles, hooks or rakes, or were lifted up from the surface.

The account of this miracle reveals a striking double standard of compassion. Some forty-odd members of the community were willing to spend six hours on their knees praying for one of their own, but there were those among them who had shown a

${ }^{78}$ Cantilupe proc., pp. 610-13. 


\section{Eleanora C. Gordon}

callous disregard for the child of a beggar woman. Only one, a servant, wished to report the finding of a body. We do not know if he was motivated by fear of the law or a desire to help. The possibility that the submerged body might still be alive never occurred to the merry dancers from the tavern. Nor is any indignation over the beggar woman's presumed infanticide recorded. Like many in our own time, they simply did not want to get involved. Finders of bodies were required to notify the coroner whose duty it was to investigate sudden, suspicious, and violent deaths. The coroner secured by attachment the presence of all persons who found the corpse before the local justices. ${ }^{79}$ This is the only example of apathy toward a child, however, in the 135 miracles studied. Many of the accounts describe the kindness of sympathetic strangers.

\section{CHILDREN AND ACCIDENTS THEN AND NOW}

These 134 children and adolescents had an astonishing ability to survive serious injury without benefit of medical help. Although some had the advantage of timely rescues, many suffered injuries which might have been fatal. Their bodies usually healed quickly. The miracle accounts, of course, tell us only about survivors. Coroners' records describe many accidental deaths in children.$^{80}$ Not surprisingly, later writings tell us that children's accidents and the circumstances which cause then have not changed. Children in seventeenth-century colonial America fell into fireplaces, drowned, or scalded themselves in cooking pots. ${ }^{81}$ Some of the most distinguished physicians in eighteenth-century Philadelphia could not extract a nutshell from little Eliza Drinker's nostril. ${ }^{82}$ Among the hazards cited in a book on prevention of children's accidents, published in New Haven in 1830, were falls, burns, drowning, playing with knives, playing with horses, being tossed by a bull, "troubling the cook", and climbing trees. ${ }^{83}$ Modern children also fall out of trees, nearly drown in bathtubs, buckets, barrels, rivers, and ponds. They put beans up their noses and in their ears, and they choke on small objects. Throughout the years, then, normal behaviour of children, coupled at times with inconsistent supervision, has put them at risk for common types of accidental injuries.

Theories about the evolution of a notion of childhood have become well known subjects of controversy in recent years. Ariès's view that the concept of childhood did not exist and that there was no place for children in the medieval world is supplemented by the more extreme view of de Mause. The latter has written that "the history of childhood is a long nightmare from which we have only begun to awaken. The further back in history one goes, the lower the level of child care and the more

\footnotetext{
${ }^{79}$ See R. F. Hunnisett, The medieval coroner, Cambridge University Press, 1961, pp. 9-36, for a history of the office and an explanation of the coroners' duties.

${ }^{80} \mathrm{See}$, for example, Hanawalt, op. cit., note 11 above for a description and analysis of accounts of fatalities in children found in coroners' records.

${ }_{81}$ Thomas E. Cone, Jr., History of American pediatrics, Boston, Little, Brown \& Co., 1979, p. 20.

82 Ibid., p. 47.

83 Thomas E. Cone, Jr. (ed.), The book of accidents: designed for young children (New Haven, S. Babcock, 1830) in Pediatrics, 1970, 46: 138-9, 312, 472, 636, 810, 967; 1971, 47: 148, 460, 623, 784, 947, 1074; 1971, 48: $151,324,482,656,839$.
} 


\section{Accidents among medieval children}

likely children are to be killed, abandoned, beaten, terrorized, and sexually abused". 84 On the other hand, Demaitre, Kroll and Bachrach, and Shahar, among others, have questioned these extreme views. ${ }^{85}$

This study provides additional specific evidence that "childhood" did indeed exist in the Middle Ages. The children who appear in these records enjoyed their childhood. Their parents were well aware of typical childish traits and sometimes chastised themselves for overlooking them. Medieval youngsters, like their modern counterparts, were inquisitive, adventurous, inexperienced, and often poorly supervised. Little ones wandered off, older children played in groups, and adolescents, who could be moody, inattentive, and immature, were sometimes heroic. Even the clerical editors of the miracle accounts, who had no direct contact with children, described the particularly childish characteristics which led to the mishaps. Moreover, the miracle accounts show that most of the parents loved their offspring and were physically and emotionally close to them. They cuddled them and soothed them. Family members and neighbours banded together to sustain each other through the crises and shared their joy at the recovery. Clearly, then, children had a special and distinct place in their society.

The accidental injuries described in these 134 children and adolescents are those which one would expect to find in youngsters engrossed in normal childish activity. In these records parents, who were devoted to their offspring, were well aware of specific aspects of behaviour which were age-appropriate for children and adolescents. The records of these recoveries, described in the posthumous miracles of six English saints, not only provide a glimpse of reliance on faith and prayer as an instrument of healing, but also a window on childhood in an age when some have said childhood did not exist.

\footnotetext{
${ }^{84}$ Lloyd de Mause, 'The evolution of childhood', in de Mause (ed.), The history of childhood, New York, Psychohistory Press, 1974, p. 1.

${ }^{85}$ Luke Demaitre, 'The idea of childhood and child care in the medical writings of the Middle Ages', $J$. Psychohist., 1977, 4: 461-90; Jerome Kroll and Bernard Bachrach, 'Child care and child abuse in early medieval Europe', J. Am. Acad. Child Psychiat., 1986, 25: 562-568; Shulamith Shahar, Childhood in the Middle Ages, London, Routledge, 1990, pp. 1-7.
} 